\title{
EXPERIMENTAL STUDY ON GLASS FIBER REINFORCED GYPSUM (GFRG) PANELS FILLED WITH ALTERNATE CONCRETE MIX USING FLY ASH
}

\author{
Pankaj Kumar \\ Department of Civil Engineering \\ Delhi Technical Campus Greater Noida, Uttar Pradesh, India \\ (Guru Gobind Singh Indraprastha University, New Delhi)
}

\begin{abstract}
There is a substantial growing demand for housing in India as the population increase rate is skyrocketing. More and more people are shifting from rural to urban areas day by day, making urban areas denser. The Ministry of Rural Development assessed that India's rustic housing lack remains at $\mathbf{4 4}$ million dwelling units. India's metropolitan housing lack has risen $\mathbf{5 4}$ percent to 29 million out of 2018 from 18.78 million of every 2012, of which $96 \%$ relates to Economically Weaker Section (EWS) and Low-Income Group (LIG) type, according to the gauge of the Ministry of Housing and Urban Poverty Alleviation.
\end{abstract}

To address these difficulties, India requires innovative, energy-effective structure materials for a reliable, quick, and tough housing strategy for development at a moderate expense. It is likewise significant that housing structures are catastrophes impervious to secure individuals' lives and properties. Every one of these worries is engaged with a maintainable and comprehensive turn of events. One such strategy to accomplish that is by utilizing Glass Fiber Reinforced Gypsum (GFRG) panels. They serve the purpose of fast construction and be cost-efficient, earthquake-resistant, best suitable for the financially Indian backward class of people and in the country's earthquake-prone regions like Gujarat.

The phosphogypsum's effective disposal is achieved through the Glass Fiber Reinforced Gypsum (GFRG) panel, also known as Rapid wall. These can be used as load-bearing as well as non-load-bearing structures. To use GFRG in load-bearing buildings, M20grade concrete is used as a filling material to overcome the hurdles provided by gravity and other factors. M20 grade concrete is used in these panels to satisfy the minimum requirements mentioned in IS 456:2000.

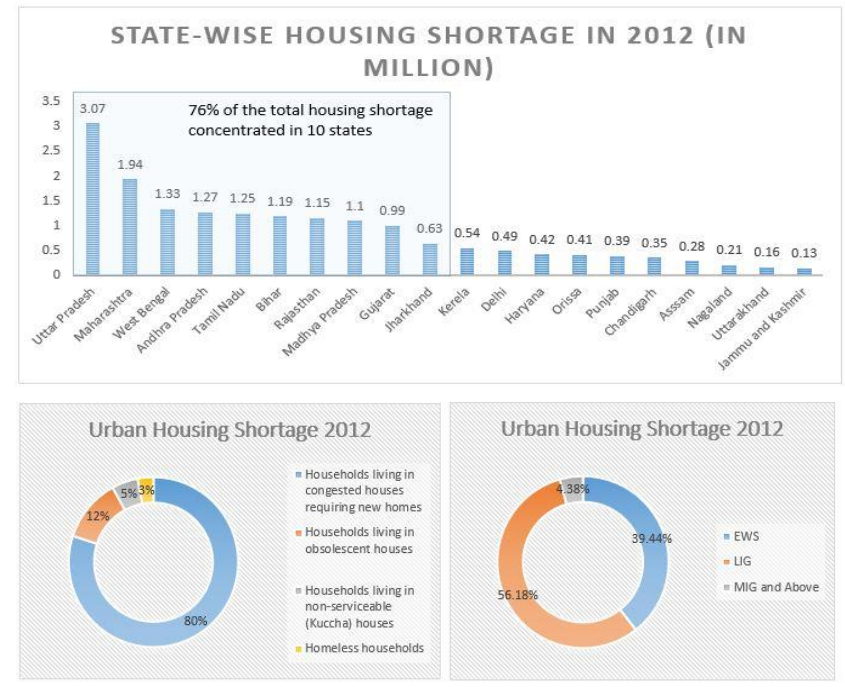

Fig 1. Housing Shortages in India

Keywords- Glass Fibre Reinforced Gypsum (GFRG) panels, Concrete Mix, Fly ash aggregates (FAA), Fly ash Fine Aggregates (FAFA), Fly ash Coarse Aggregate (FACA), Fly ash Aggregate Concrete (FAAC), Compressive Strength, Split tensile strength, Flexural strength, Control concrete (CC)

\section{INTRODUCTION}

Glass fiber reinforced gypsum (GFRG) panels or Rapid walls are among the most advanced building methods in today's era. It is developed by the GFRG Building System Australia for mass-scale development of houses in a limited capacity of time and money to meet the people's needs. GFRG panels are manufactured using calcined strengthened gypsum mortar, with glass strands that, when combined with fortified cement to an applicable extent, get sufficiently able to go about as a heap bearing 


\section{International Journal of Engineering Applied Sciences and Technology, 2021 \\ Vol. 5, Issue 11, ISSN No. 2455-2143, Pages 267-273 \\ Published Online March 2021 in IJEAST (http://www.ijeast.com)}

shear divider. GFRG boards can withstand the tremor up to 8 on the Richter scale. Rapid Wall Panel gives quicker development. The paper depicts the strategy for development utilizing Rapid wall panels dependent on the development manual arranged by IIT Madras to suit Indian circumstances. Certainty and RCF, two compost monsters under the open area, set up Rapid wall and mortar items fabricating plant at Ambalamugal utilizing Rapid wall advancements of Australia called FACT RCF Building items Ltd. (FRBL). More than 7 million ton of gypsum is available as produces as residue from factories. By setting up Rapid wall and Plaster items plant, they mean to create 1.4 million sqm or 15 million sq $\mathrm{ft}$ board each year and around 50000 tons of predominant quality wall mortar and wall clay, answering large numbers of the above issues and concern.

A concrete mix of ordinary Portland cement was used in the conventional method of preparing the filling material for the GFRG panels. Still, it is heavy in weight due to its high density ranging between 2200 to $2600 \mathrm{Kg} / \mathrm{m} 3$, which results in the increment of self-weight of the building. This creates a big problem. An alternate mix of concrete is to be prepared with desired low density by using fly ash to overcome this problem. This results in the reduction of the building's cost as the fly ash is a waste of the coal industry, and there is a need to reduce this waste as it will cause severe problems in the future. This leads to the development of lightweight concrete. Lightweight concrete is defined as a concrete that has been made lighter than the conventional concrete by changing the material composition or production methods. Lightweight aggregate concrete is the concrete produced by replacing the usual material aggregate with lightweight aggregates. Lightweight concrete cannot fulfill the demand of strength potential but serves to reduce and thus provide economic structures and enhanced seismic resistance, high sound absorption, and good fire resistance. Because of the above reasons, the study on fly ash aggregates concrete is conducted to increase the cost efficiency of a building using GFRG panels.

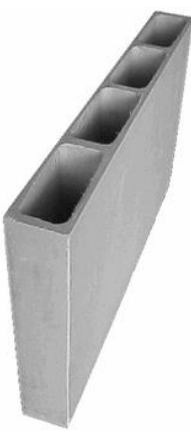

(a) GFRG panel

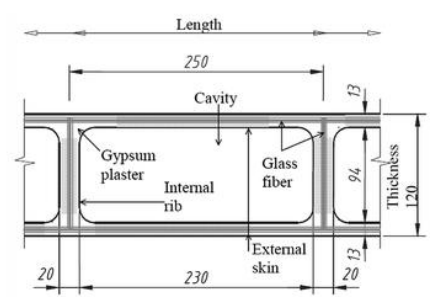

(b) Cross-sectional details

\section{MATERIALS AND MethodS}

To prepare the test specimens, the following materials were used.

i) $\quad 43$ grade Ordinary Portland cement was used for the study as per IS:8112-19899.

ii) Fly ash wash collected Mettur Thermal power plant confirming IS: 3812-19811

iii) River sand belonging to IS Grading Zone II: 383-1970 was used in preparing the concrete as it is easily available nearby.

iv) "Fly ash Fine Aggregate (FAFA) obtained from cement fly ash ratios of 10:90, $12.5: 87.5,15: 85,17.5: 82.5,20: 80$ and $20: 80$ respectively." [2]

v) "Hard Broken Granite Stone (HBG) confirming the size of $20 \mathrm{~mm}$ graded aggregate as per IS: 383-1970.” [2]

vi) "Fly ash Coarse Aggregates (FACA) collected from cement fly ash of proportion $10: 90,12.5: 87.5,15: 85,17.5: 77.5,20: 80$ and 22.5:77.5." [2]

vii) Bore well water for mixing and curing specimens.

\section{PROPERTIES OF AGGREGATES}

Table 1. Physical properties of Conventional Fine Aggregate (CFA) and Fly ash fine aggregate (FAFA)

\begin{tabular}{|c|l|l|l|}
\hline S. No & \multicolumn{1}{|c|}{ Properties } & \multicolumn{1}{c|}{ CFA } & (FAFA) \\
\hline 1 & $\begin{array}{l}\text { Specific } \\
\text { gravity }\end{array}$ & 2.70 & 1.28 \\
\hline 2 & $\begin{array}{l}\text { Bulk density } \\
\left(\mathrm{Kg} / \mathrm{m}^{3}\right)\end{array}$ & 1808 & 838 \\
\hline 3 & Size $(\mathrm{mm})$ & Below 4.75 & Below 4.75 \\
\hline 4 & $\begin{array}{l}\text { Fineness } \\
\text { modulus }\end{array}$ & 2.68 & 2.70 \\
\hline
\end{tabular}

Fig 2. GFRG Panels 


\section{International Journal of Engineering Applied Sciences and Technology, 2021 \\ Vol. 5, Issue 11, ISSN No. 2455-2143, Pages 267-273 \\ Published Online March 2021 in IJEAST (http://www.ijeast.com)}

Table 2. Physical properties of Conventional Coarse Aggregate (CCA) and Fly ash Coarse Aggregate (FACA)

\begin{tabular}{|c|l|l|l|}
\hline S. No & \multicolumn{1}{|c|}{ Properties } & \multicolumn{1}{|c|}{ CCA } & \multicolumn{1}{c|}{ FACA } \\
\hline 1 & Shape & Angular & Spherical \\
\hline 2 & $\begin{array}{l}\text { Specific } \\
\text { gravity }\end{array}$ & 2.75 & 1.3 \\
\hline 3 & $\begin{array}{l}\text { Bulk density } \\
\left(\mathrm{Kg} / \mathrm{m}^{3}\right)\end{array}$ & 1685 & 913 \\
\hline 4 & Size $(\mathrm{mm})$ & $\begin{array}{l}4.75 \mathrm{~mm} \text { to } \\
20 \mathrm{~mm}\end{array}$ & $\begin{array}{l}4.75 \mathrm{~mm} \text { to } \\
20 \mathrm{~mm}\end{array}$ \\
\hline 5 & $\begin{array}{l}\text { Crushing value } \\
(\%)\end{array}$ & 24.94 & 25.6 \\
\hline 6 & $\begin{array}{l}\text { Impact Value } \\
(\%)\end{array}$ & 23.86 & 21.6 \\
\hline
\end{tabular}

Table 3. Chemical Composition of Fly Ash (Class F)

\begin{tabular}{|c|c|c|c|}
\hline \multicolumn{4}{|c|}{ Chemical Composition } \\
\hline \multicolumn{2}{|c|}{ Constituent } & \multirow{2}{*}{$\begin{array}{r}\text { World } \\
\text { Std. \% }\end{array}$} & \multirow{2}{*}{$\begin{array}{l}\text { Fly ash used in } \\
\text { thesis work } \% \\
54.92\end{array}$} \\
\hline Silica & $\mathrm{SiO}_{2}$ & & \\
\hline Alumina & $\mathrm{Al}_{2} \mathrm{O}_{3}$ & 31.45 & 23.04 \\
\hline Ferric Oxide & $\mathrm{Fe} 2 \mathrm{O}_{3}$ & 1.87 & - \\
\hline $\begin{array}{l}\text { Titanium } \\
\text { Dioxide }\end{array}$ & $\mathrm{TiO}_{2}$ & 1.45 & - \\
\hline $\begin{array}{l}\text { Manganese } \\
\text { Oxide }\end{array}$ & $\mathrm{MnO}$ & 0.005 & - \\
\hline Calcium Oxide & $\mathrm{CaO}$ & 0.40 & 3.84 \\
\hline $\begin{array}{l}\text { Magnesium } \\
\text { Oxide }\end{array}$ & $\mathrm{MgO}$ & 0.38 & 2.82 \\
\hline Sodium Oxide & $\mathrm{Na}_{2} \mathrm{O}$ & 0.05 & - \\
\hline Potassium Oxide & $\mathrm{K}_{2} \mathrm{O}$ & 0.82 & - \\
\hline Iron & $\mathrm{FE}_{2} \mathrm{O}$ & - & 6.62 \\
\hline Phosphorus & $\mathrm{P}_{2} \mathrm{O}_{5}$ & - & 0.30 \\
\hline $\begin{array}{l}\text { Alkalimetal's } \\
\text { Oxide }\end{array}$ & & - & 2.70 \\
\hline Sulphur & $\mathrm{SO}_{3}$ & - & 0.76 \\
\hline Magnesium & Mgo & - & 2.82 \\
\hline Loss on Ignition & LOI & 1.0 & 2.88 \\
\hline
\end{tabular}

Table 4. Comparison of Workability of FAAC with Conventional Concrete

\begin{tabular}{|l|c|c|c|c|}
\hline \multirow{2}{*}{} & \multicolumn{4}{|c|}{ Workability Test } \\
\cline { 2 - 5 } & & \multicolumn{3}{|c|}{} \\
\hline $\begin{array}{l}\text { Control } \\
\text { concrete }\end{array}$ & 40 & Medium & 0.91 & High \\
\hline $\begin{array}{l}\text { Fly ash } \\
\text { aggregate } \\
\text { concrete }\end{array}$ & 60 & Medium & 0.9 & High \\
\hline
\end{tabular}

\section{EXPERIMENTAL PROCEDURE}

A. The first stage of the experiment consists of formation of fly ash aggregate. The main constituents taken are cement, fly ash and water. Water acts as a binding agent.

B. Cement and fly ash are taken in the ratio 10:90, 12.5:87.5, 15:85, 17.5:82.5, 20:80 and 22.5:77.5

C. A mixture was prepared of cement and fly ash and mixed in a drum using the above ratios. Water was added with the water cement ratio of 0.3 . This method of formation of fly ash aggregates is called palletization.
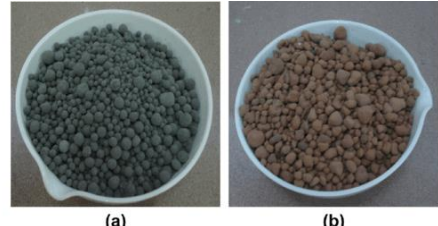

Fig 2. Fly ash Aggregates

D. Fly ash aggregates were removed from the mixer, dried for a day and then cured for 7 days in a water tank.

E. The aggregates were segregated after curing according to their size.

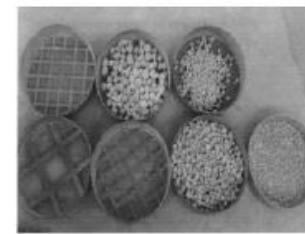

Fig 3. Segregation of fly ash aggregates 
Published Online March 2021 in IJEAST (http://www.ijeast.com)

F. A mix design for M20 grade concrete was prepared confirming suitable IS method taking the mix proportion of 1:1.53:2.68:0.5

G. For casting of test specimens, concrete cubes of different aggregates were tested including conventional fine aggregate (CFA) and conventional coarse aggregate (CCA) and using fly ash fine and fly ash coarse aggregates.

\section{RESULTS AND DISCUSSION}

\section{A. Compression Test}

“As per IS $516-1959,15 \mathrm{~cm} \times 15 \mathrm{~cm} \times 15 \mathrm{~cm}$ concrete cubes were tested. The test was performed on the compression measuring machine 120T. At a rate of approximately $140 \mathrm{~kg} / \mathrm{cm} 2 / \mathrm{min}$, the load was applied until the specimen failed. The maximum load applied to the specimen until failure was documented and shown in Table-5." [2]

Table 5. Compressive strength of fly ash aggregate concrete and control concrete with different ages of testing

\begin{tabular}{|c|c|c|}
\hline $\begin{array}{l}\text { Age of } \\
\text { testing }\end{array}$ & $\begin{array}{l}\text { Proportion } \\
\text { Cement : Fly } \\
\text { ash }\end{array}$ & $\begin{array}{c}\text { Compressive Strength in } \\
\qquad \mathrm{N} / \mathrm{mm}^{2}\end{array}$ \\
\hline \multirow{7}{*}{1 day } & $10: 90$ & 2.62 \\
\hline & $12.5: 87.5$ & 2.76 \\
\hline & $15: 85$ & 3.84 \\
\hline & $17.5: 82.5$ & 2.57 \\
\hline & $20: 80$ & 2.21 \\
\hline & $22.5: 77.5$ & 2.13 \\
\hline & $\begin{array}{l}\text { Control } \\
\text { concrete }\end{array}$ & 3.33 \\
\hline \multirow{3}{*}{3 days } & $10: 90$ & 6.41 \\
\hline & $12.5: 87.5$ & 6.55 \\
\hline & $15: 85$ & 9.43 \\
\hline
\end{tabular}

\begin{tabular}{|c|c|c|}
\hline & $17.5: 82.5$ & 6.81 \\
\hline & $20: 80$ & 6.61 \\
\hline & $22.5: 77.5$ & 6.28 \\
\hline & $\begin{array}{l}\text { Control } \\
\text { concrete }\end{array}$ & 8.37 \\
\hline \multirow{7}{*}{7 days } & $10: 90$ & 11.62 \\
\hline & $12.5: 87.5$ & 12.89 \\
\hline & $15: 85$ & 15.93 \\
\hline & $17.5: 82.5$ & 13.10 \\
\hline & $20: 80$ & 12.90 \\
\hline & $22.5: 77.5$ & 10.24 \\
\hline & $\begin{array}{l}\text { Control } \\
\text { concrete }\end{array}$ & 14.34 \\
\hline \multirow{7}{*}{14 days } & $10: 90$ & 14.20 \\
\hline & $12.5: 87.5$ & 15.60 \\
\hline & $15: 85$ & 20.24 \\
\hline & $17.5: 82.5$ & 16.20 \\
\hline & $20: 80$ & 15.80 \\
\hline & $22.5: 77.5$ & 12.60 \\
\hline & $\begin{array}{l}\text { Control } \\
\text { concrete }\end{array}$ & 17.62 \\
\hline \multirow{7}{*}{28 days } & $10: 90$ & 16.30 \\
\hline & $12.5: 87.5$ & 17.23 \\
\hline & $15: 85$ & 23.71 \\
\hline & $17.5: 82.5$ & 17.90 \\
\hline & $20: 80$ & 17.20 \\
\hline & $22.5: 77.5$ & 14.80 \\
\hline & $\begin{array}{l}\text { Control } \\
\text { concrete }\end{array}$ & 20.80 \\
\hline \multirow{7}{*}{56 days } & $10: 90$ & 17.12 \\
\hline & $12.5: 87.5$ & 18.26 \\
\hline & $15: 85$ & 25.35 \\
\hline & $17.5: 82.5$ & 19.20 \\
\hline & $20: 80$ & 18.32 \\
\hline & $22.5: 77.5$ & 16.19 \\
\hline & $\begin{array}{l}\text { Control } \\
\text { concrete }\end{array}$ & 22.44 \\
\hline \multirow{3}{*}{90 days } & $10: 90$ & 19.10 \\
\hline & $12.5: 87.5$ & 19.40 \\
\hline & $15: 85$ & 27.03 \\
\hline
\end{tabular}


International Journal of Engineering Applied Sciences and Technology, 2021

Vol. 5, Issue 11, ISSN No. 2455-2143, Pages 267-273

Published Online March 2021 in IJEAST (http://www.ijeast.com)

\begin{tabular}{|l|l|l|}
\hline & $17.5: 82.5$ & 20.18 \\
\cline { 2 - 3 } $20: 80$ & 19.54 \\
\cline { 2 - 3 } $22.5: 77.5$ & 18.64 \\
\cline { 2 - 3 } $\begin{array}{l}\text { Control } \\
\text { concrete }\end{array}$ & 24.96 \\
\hline
\end{tabular}

Table 7. Flexural strength of fly ash aggregate concrete and control concrete at different ages of testing

\section{B. Split Tension Test}

Dimensions of the concrete cylinders: Diameter: $15 \mathrm{~cm}$, Height: $30 \mathrm{~cm}$

Concrete cylinders were tested confirming to IS 58161976.

Table 6. Split tensile strength of fly ash aggregate concrete and control concrete with different ages of testing

\begin{tabular}{|c|c|c|}
\hline $\begin{array}{c}\text { Age of } \\
\text { testing }\end{array}$ & $\begin{array}{c}\text { Proportion } \\
\text { Cement }: \text { Fly ash }\end{array}$ & $\begin{array}{c}\text { Splitting tensile } \\
\text { Strength in } \\
\text { N/mm }\end{array}$ \\
\hline \multirow{3}{*}{7 days } & $10: 90$ & 3.15 \\
\cline { 2 - 3 } & $12.5: 87.5$ & 3.45 \\
\cline { 2 - 3 } & $15: 85$ & 4.60 \\
\cline { 2 - 3 } & $17.5: 82.5$ & 3.20 \\
\cline { 2 - 3 } & $20: 80$ & 3.05 \\
\cline { 2 - 3 } 28 days & $22.5: 77.5$ & 2.95 \\
\cline { 2 - 3 } & Control concrete & 4.10 \\
\cline { 2 - 3 } & $10: 90$ & 3.70 \\
\cline { 2 - 3 } & $12.5: 87.5$ & 4.10 \\
\cline { 2 - 3 } & $15: 85$ & 5.56 \\
\cline { 2 - 3 } & $17.5: 82.5$ & 3.90 \\
\cline { 2 - 3 } & $20: 80$ & 3.65 \\
\cline { 2 - 3 } & $22.5: 77.5$ & 3.20 \\
\cline { 2 - 3 } & Control concrete & 4.84 \\
\hline
\end{tabular}

\section{Flexural Strength Test}

Dimensions of the concrete beams tested: $10 \mathrm{~cm} \times 10 \mathrm{~cm}$ $\mathrm{x} 50 \mathrm{~cm}$

The concrete beams were tested confirming to IS 5161959.

\begin{tabular}{|c|c|c|}
\hline $\begin{array}{l}\text { Age of } \\
\text { testing }\end{array}$ & $\begin{array}{c}\text { Proportion } \\
\text { Cement : Fly ash }\end{array}$ & $\begin{array}{c}\text { Flexural Strength } \\
\text { in } \\
\mathbf{N} / \mathbf{m m}^{2}\end{array}$ \\
\hline \multirow{7}{*}{7 days } & $10: 90$ & 4.10 \\
\hline & $12.5: 87.5$ & 4.50 \\
\hline & $15: 85$ & 5.49 \\
\hline & $17.5: 82.5$ & 4.40 \\
\hline & $20: 80$ & 4.20 \\
\hline & $22.5: 77.5$ & 3.95 \\
\hline & Control concrete & 4.95 \\
\hline \multirow{7}{*}{28 days } & $10: 90$ & 4.40 \\
\hline & $12.5: 87.5$ & 4.75 \\
\hline & $15: 85$ & 6.22 \\
\hline & $17.5: 82.5$ & 4.60 \\
\hline & $20: 80$ & 4.35 \\
\hline & $22.5: 77.5$ & 4.15 \\
\hline & Control concrete & 5.36 \\
\hline
\end{tabular}

Fig 4. Comparison of Compressive strength of fly ash aggregate concrete and control concrete vs Number of days of curing

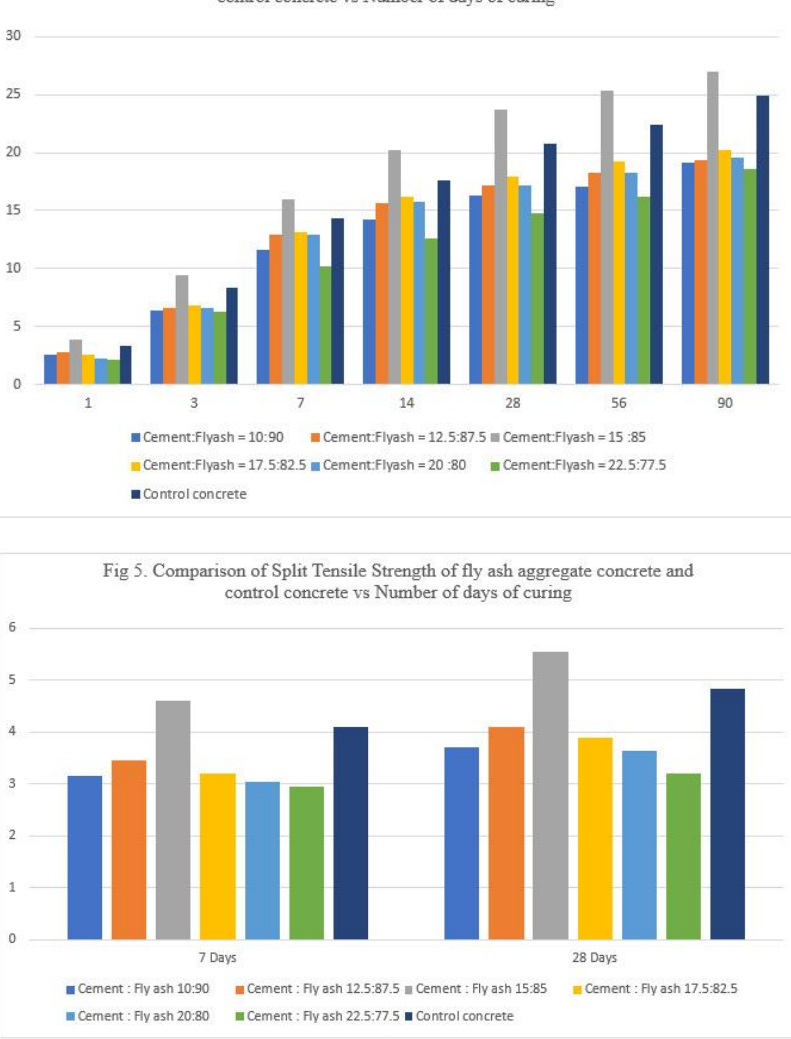




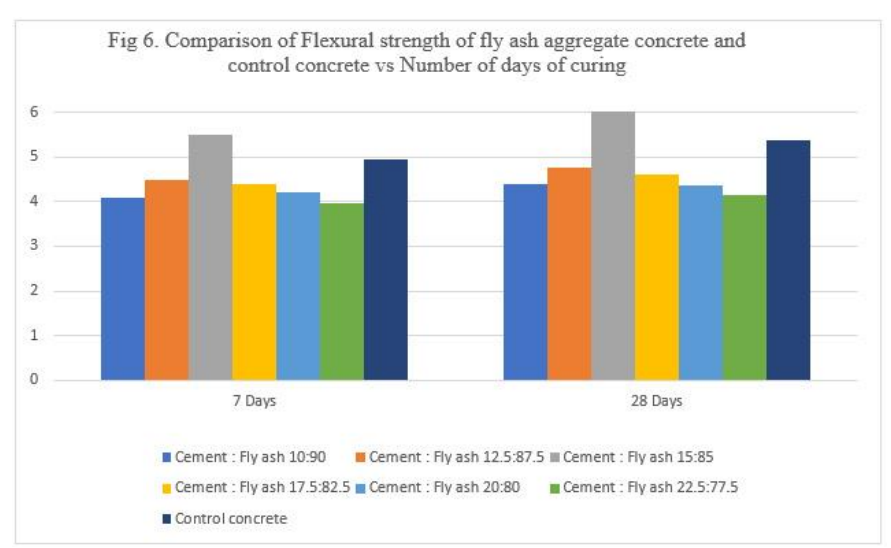

\section{CONCLUSION}

i) Compared to control concrete cubes at all curing ages, the compressive strength for fly ash aggregate concrete cubes with a cement fly ash ratio of 15:85 was increased.

ii) Compared to the control concrete beams, the split tensile strength of fly ash aggregate concrete beams with fly ash aggregates of cement fly ash ratio 15:85 was improved at all ages of 7 days and 28 days compared to the control concrete beams

iii) Compared to the control concrete at the ages of 7 days and 28 days of curing, the increase in flexural strength of the sample was observed for the fly ash aggregate concrete containing fly ash aggregates made using cement fly ash ratio of 15:85.

iv) The use of fly ash as an aggregate in concrete mix for filling the GFRG panels increases the compressive strength, split tensile strength and flexural strength when mix the ratio of Cement : Fly ash was 15:85.

v) Using fly ash as an aggregate solves the problem of waste in coal industries.

vi) The weight of the concrete cubes compared to the conventional concrete is reduced to about $27.5 \%$ by weight.

vii) The increasing demand for housing can be fulfilled by GFRG panels with good and light weight aggregate concrete mix using fly ash to provide better strength and resistivity towards earthquakes.

viii) There is an increasing issue of natural resource depletion in the world. So, we have to come up with some ecofriendly methods to meet the demands the people and using fly ash in concrete mix is one such method.

\section{REFERENCE}

[1] NithyaNandan A, Renjith R "Experimental Study on Glass Fiber Reinforced Gypsum (GFRG) Panels Filled with Alternate Concrete Mix Using Shredded Thermocol and Phosphogypsum"

[2] S. Shanmugasundaram, Dr. S. Jayanthi, Dr. R. Sundararajan, Dr. C. Umarani, Dr. K. Jagadeesan "Study on Utilization of Fly Ash Aggregates in Concrete"

[3] "Use of Glass Fibre Reinforced Gypsum (GFRG) Panels in Buildings, Structural Design Manual", Structural Engineering Division IIT Madras.

[4] C. V. SIVA RAMA PR, "Light Weight Concrete using Fly Ash Aggregate"

[5] Byung-Wan Jo, Seung-Kook Park and Jang-Bin Park. (2006). "Properties of concrete made with alkali activated fly ash light weight aggregate", Cement and Concrete composites (2006), PP 1 to 8.

[6] Dr. J.P. Behera, Dr. H.S. Ray, Dr. B.D. Nayak and Dr. B. Sarangi. (2004). "Light weight concrete with sintered fly ash aggregates". A study on partial replacement to normal granite aggregate. Institution of Engineers, India (IE(I)) Journal - CV Vol 85 August'2004, PP 84 to 87.

[7] Gao Li-Xiang, Yao Yan and Wang Ling. "Research on sintered fly ash aggregate of high strength and low absorption of water", Proceedings of International workshop on Sustainable development and Concrete Technology, PP 151 to 157.

[8] Gokhan Banjkal, Ata Gurhan Doren. (2000). "Utilisation of fly ash by pelletization process", application of areas and research results, resources, conservation and recycling 30 (2000), PP 59 to 77.

[9] IS 10262-1982 recommended guide lines for concrete mix design.

[10] M.S.Shetty. (2005)." Concrete Technology", S. Chand and Co Publishing Company, pp 53 to 62.

[11] Mehmet Gesoglu, Turen Oztumn and Guneyisi (2006), "Effects of cold bonded fly ash aggregate properties on the shrinkage cracking of light weight concretes", cement and concrete composites 28(2006) PP $592-605$.

[12] Neville A.M. (1995). "Properties of concrete", IV Ed Longman, 824p.

[13] P. Kumar Mehta and Paulo J.M. Monteiro. "Concrete Microstructure, Properties and Materials" pp 226 to 230

[14] Rajamani N.P, Annie peter J., Sabitha D. and Gopalakrishanan S. (2004)." Studies on development on bonded fly ash aggregates for use as coarse aggregate in structural grade concretes" New building materials and construction world Vol 10, issue 4, Oct (pp 60 to 70).

[15] Rajamani N.P and Ambily P.S. (2006). "Selection of mortar for light weight aggregate concrete made with fly 
International Journal of Engineering Applied Sciences and Technology, 2021

Vol. 5, Issue 11, ISSN No. 2455-2143, Pages 267-273

Published Online March 2021 in IJEAST (http://www.ijeast.com)

ash-based aggregate", New building materials and construction world journal June 2006(pp: 80 to 88)

August 2006. 